\title{
Suffering and Prayer in the Messianic Community of Jas 5:13a
}

\author{
CHRISTOPHER NASERI \\ University of Calabar \\ paxcasa@yahoo.com, ORCID: 0000-0002-3242-4030
}

\begin{abstract}
Jas 5:13a encourages anyone within the community who suffers to pray. The text does not, however, specify whether the prayer is for the elimination of suffering or for the grace to endure it. The aim of this work, therefore, is to identify the purpose of the prayer proposed in v. 13a. The method employed is an analysis of v. 13a in its immediate context of Jas 5:13-18. The study reveals that the phrase "prayer of faith" in v. 15a offers significant clues as to the purpose of the prayer in v. 13a. The prayer of faith is a renewal of one's commitment to God and their trust in God. The invitation to pray in v. 13a is therefore a request to reaffirm that commitment to God in time of trials. The conclusion is that James is calling on Christians who suffer to reiterate their commitment to God despite their trials, and to pray for the grace to courageously endure their challenges.
\end{abstract}

Keywords: Commitment to God, Letter of James, Messianic Community, Prayer of Faith, Steadfastness, Suffering

The epistle of James pays attention to the theme of suffering ${ }^{1}$ and testing, which is introduced in 1:12-13. Trials are to be endured with the hope of an eschatological vindication. They come with a positive value because through them the pious are tested and proven to be worthy of rewards in a victory that is God's. The epistle is addressed to a community confronted with suffering; the author understands this situation as a test ( $\pi \varepsilon \iota \rho a \sigma \mu o$ c). Through a commitment to unity, love, and cohesiveness, members of the Christian community of James must learn to put up with miseries to receive the expected eschatological rewards.

A Christian is one who is baptized in Christ's name and publicly declares themselves to be a follower of the ways set down by Christ in the Bible for life on earth. This group of people made up the community of Christians addressed by the author of the Letter of James. They were the early Diaspora Jewish followers of the apostles who congregated around the apostle James. Their emergence was in response to the apostles' preaching about Jesus as the expected Jewish Messiah. They are

1 For the notion of suffering as an existential phenomenon and the challenges it poses to a Christian, see Tripp, Suffering; Rudolfsson - Flensner, "Suffering and Suffering with the Other," 278-286. Rehnsfeldt Eriksson, "The Progression of Suffering," 264-272. 
here referred to as the 'Messianic Community' to underscore their faith in Jesus as the Messiah. This faith unites and keeps the members together as one entity with a common goal, mission, and orientation. Traditional positions on the early dating of James suggest that the community was confronted in the late 40s and 50s AD by existential problems associated with its time. ${ }^{2}$ These problems included internal bitterness, the struggle between the Zealots and the pro-Roman parties, the tension between the rich and the poor, the decision to opt for what provided an opportunity for wealth and the conflict between such opportunities and the faith of the community. ${ }^{3}$ The struggle between personal challenges of health and hunger and the quest for expected but not-fast-coming healing and relief equally necessitated unbearable suffering. This suffering came with consequent temptations to give up on the faith. It is to this community that the Letter of James 5:13a is addressed; the author invites those who suffer to pray. But the text does not specify the purpose of the prayer; if it is for the elimination of suffering or for perseverance? This article is therefore meant to provide an answer to the question above.

James Riley Strange in his commentary on the Letter of James understands this prayer as a petition for patience and endurance in the face of suffering. ${ }^{4}$ Martin C. Albl concentrates on the sick in v. 14 and understands prayer as intended to procure healing for the sick person. He identifies in the text the responsibility of the community as a family to provide equal access to health care for all its members. ${ }^{5}$ Douglas J. Moo suggests that an understanding of the prayer as a petition for the suffering to be removed is a possibility. He, however, interprets the text as a petition for the strength to endure the trial with a godly spirit. ${ }^{6}$ Robert W. Wall explains the prayer as equally implying a request for deliverance from suffering. ${ }^{7}$ Luke Timothy Johnson submits that the subject of the prayer is for relief from suffering or for the endurance to survive it. ${ }^{8}$ John Wilkinson proposes that the invitation to pray in v. 13 does not include a promise that the prayer will remove the cause of the suffering. He identifies the prayer of vv. 15 and 16 as intended to bring healing. He cautions that it is not the logic of faith for healing to always come when one prays, healing depends on the will of God. ${ }^{9}$ Kevin Condon pays attention to vv. 14-15 in the context of the sacrament of healing. He nevertheless, explains prayer in v. 13 as an invitation to raise one's mind to God rather than become cranky. ${ }^{10}$ Andrew Bowden presents

\footnotetext{
2 For details on the dating of James, see Moo, The Letter of James, 77-81; Laws, “James, Epistle of," 622-623;

Davids, The Epistle of James, 33-34. This work assumes the traditional position of early dating.

Davids, The Epistle of James, 33-34.

Strange, The Moral World of James, 27-28.

Albl, "Are Any among You Sick?", 139, 141.

Moo, The Letter of James, 514.

Wall, Community of the Wise, 264.

Johnson, The Letter of James, 329.

Wilkinson, "Healing in the Epistle of James," 328 and 337.

Condon, "The Sacrament of Healing," 35.
} 
a summary of authors' approaches to Jas 5 . His purpose is primarily to provide available literature on the subject of sickness and healing in James. He identifies the quest among authors to establish if sickness and healing are physical or spiritual or both. He acknowledges that some of these authors primarily understand the sickness as physical and the healing as both physical and spiritual. ${ }^{11}$

Most of the works reviewed above are commentaries on the Letter of James and offer a summary view of the entire letter without paying particular attention to any of the texts. Available scholarly articles deal with the entire pericope of 5:13-18 and none has sought to interpret v. 13a in the light of v. 15a. This article is particularly concerned with Jas 5:13a and the aim is to identify the intention for which the one who suffers should pray. The method is to analyse v. 13a in its immediate context of vv. 13-18 by underscoring the relevance of the phrase 'prayer of faith' in v. 15a. This phrase holds the key to discovering the purpose of the prayer in v. 13a. Prayer of faith is an affirmation of one's commitment to God and one's trust in God. Christians who suffer are thus invited in v. 13a to renew and reaffirm that commitment and trust, and not allow their trials to derail them.

The first part of this article discusses the progression in the understanding of suffering in the Bible. The progression reveals that biblically suffering is first understood as the consequence of sin against God, and subsequently as a test of virtue and faithfulness to God. This suffering can be overcome through recourse to God in prayer. In the following sections of the article, the work situates and examines v. 13a within the setting of Jas 5:13-18. The setting reveals that $v$. 13a forms part of the larger subunit of vv. 13-14 on suffering and cheerfulness, and prayer and praise. It also shows that with the theme of prayer, v. 13a resonates in vv. 15-16 and 17-18. The author encourages community solidarity and urges members to prayerfully endure their pains with the hope for eschatological reward and restoration. He invites Christians who suffer to remain conscious of the mercy and faithfulness of God and pray for the ability to persevere in their suffering and not give up. The prayer proposed by James is for the courage to endure difficult situations without having to give up one's belief in Christ. When a Christian resorts to prayer in suffering, there is hope for relief and therefore the courage to attain happiness in the midst of suffering.

\section{The Notion of Suffering in the Bible}

The Bible associates suffering generally with sin and traces it to the sin of Adam. It is equally understood as God's retribution for communal and personal sins. In the Old Testament, suffering entered the world as punishment due to the disobedience of

11 Bowden, "An Overview," 78. 
Adam and Eve (Gen 3:16-19). The entire human race is associated with this sin and its consequences. The suffering resulting from sin is experienced as a corporate reality infecting the entire community (2 Sam 24:10-17). It is seen as brought forth by God for the purpose of correcting and bringing people back to good ways (Jer 31:15-29). Suffering is, in this context, understood as an indication that wrong choices have been made and act as an incentive for the identification and correction of such choices and the avoidance of similar errors. ${ }^{12}$

The doctrine of corporate solidarity in the punishment due to individual sin was a problem for the postexilic biblical thoughts. The exilic experience of extreme suffering led to the victims' protest against suffering on account of the sins of past generations. It led to the consequent rejection of the doctrine of corporate responsibility for sin and the tendency of shifting responsibility for sin to past generations. He who sins must bear the punishment for his or her sin (Ezek 18; Jer 31:29-30; see also Deut 24:16). For Ezekiel, even the victims of the exile should accept their own individual responsibility for the unfaithfulness that leads to it and bear the calamity of the exile.

Despite this position, the apparent prosperity of the wicked and the perceived suffering of the just even in the hands of the unrighteous were challenged as unjust and contradictory (Ps 34[35]; 87[88]; Job 3:3-12). Attempts at resolving this (Ps 36[37]; 72[73]) are made in the juxtaposition of God's providence and wisdom with the suffering of the just in the light of eternal reward and punishment in the after-life (Wis 1-5; Dan 12:1-3). Those who suffer are thus convinced that their current state of suffering is temporal; it will come to an end either in this world or in a new world that is still within the framework of history as is known today.

The approach to suffering thus takes on the phase of intellectual quest for meaning and lamentations in the Books of Lamentations, Job, and the Psalms, with questions of 'why' directed to God especially on the plight of the just (Ps 43; 44; 137; Job 19:5-13). The contribution of the lamentation approach consists in the context of frank dialogue with Yahweh that it provides as a coping strategy. This serves as a structured avenue through which God's attention is drawn to one's suffering, and translates as prayer. In the final phase of the development of this doctrine, suffering is understood not only as punishment for sin but also as the test of a person's virtue and faithfulness to God in Sir 2:4 and Wis 3:5. Thus Second Isaiah takes a more hopeful and future-oriented approach to suffering. It proposes to the later generations of the exile that suffering always paves way for the fulfilment of the divine plan when taken in faith. Through the acceptance of suffering Yahweh's servants are able to make reparation for the sins of others. The suffering of Yahweh's faithful servant produces greater good from God for others. This notion is anticipated in the Story of Joseph (Gen 37; 39-46). It is understood as vicarious suffering

12 Simundson, "Suffering," 221. 
explained in the hymns of the 'Suffering Servant' in Isa 42:1-4; 49:1-7; 50:4-11; $52: 13-53: 12 . .^{13}$

Influenced by the wisdom books, Christian tradition has in the epistle of James appropriated immensely and enhanced the wisdom literature understanding of suffering as a test of one's faithfulness to God (Jas 1:2-3, 12; 5:11). For James, this notion follows from the fact that Christians hold the faith that is of the Lord Jesus Christ (Jas 2:1). They are required to learn from suffering and to learn patience from the prophets who spoke in the name of the Lord (Jas 5:10). They are to be conscious of the steadfastness of Job and his consequent reward of happiness from the Lord (5:11). Members of the messianic community of James are to appreciate and accept their suffering as proof of their steadfastness, confident that the compassionate God will reward them. Christian suffering is therefore identified in James as a means for the attainment of happiness because happiness is God's reward for those who are steadfast (5:11a).

The Pauline view on suffering is Christ-centred; it is understood as a divine instrument (Rom 5:1-9; Eph 1:7-10, 20-23). It makes Christ the one who suffers, into a model to be followed. ${ }^{14}$ Christians have been baptized into Christ's death and resurrection (Rom 6:3-5). Just as Christ had to suffer to merit redemption for humankind, and enter into his glory, so must his followers learn to accept persecution for the sake of Christ (Phil 1:29). The suffering of a Christian has a purpose; that of making up for what is lacking in the suffering of Christ and his Church (Col 1:24). It produces perseverance (Rom 5:3-4) and is an avenue for the attainment of glory that outweighs the present experience of displeasure (Rom 8:18).

The synoptic traditions depict Christ's experience of suffering as a vicarious one for the redemption of humanity. The novel and wholesome attitude of Jesus to suffering (Mark 8:31) is shown in his ready disposition to accept what God would will (Mark 14:36; Matt 26:39). He accepts it as a voluntary offer made for the redemption of humanity and his own glorification (Luke 24:25-26). Thus suffering is presented from the point of view of Christ, as an instrument for the manifestation and acceptance of God's will. It is a means for the redemption of humankind (Luke 23:31), and a channel for the attainment of Joy (Matt 5:10-12) and the glorification of Christ.

The Christian kerygma in Acts represents Jesus' suffering as an event that was, in the definite plan of God, destined for Jesus' glorification and the salvation of humankind (Acts 2:23-24; 3:13-15; 4:10-12). Though inflicted by humans, suffering when accepted and undertaken in God's name produces a victory that is God's vindication.

Christian tradition, therefore, redefines the post-exilic attitude to suffering and its challenging corporate dimension by presenting suffering as a reality to be embraced. For the Christian tradition, therefore, suffering though challenging is

\footnotetext{
13 Bukovsky, "Suffering," 776.

14 Kremer, "זá $\chi \chi \omega, " 51-52$.
} 
temporal and an avenue for the attainment of victory. For Christ's people, it is an opportunity to corporate with God's will and plans for the good of the victim and others. It is a means for the attainment of something good, likeable, and positive. Thus while the exilic experience led to a rejection of corporate participation in suffering due to the sin of other members of the people of God, Christ's redemptive suffering leads to an acceptance of suffering as God's will for the benefit of the one who suffers and for others.

\section{A Study of Jas 5:13a within the Context of Jas 5:13-18}

\subsection{The Outline of the Pericope}

Jas 5:13a belongs to the pericope of Jas 5:13-18 which forms part of a larger pericope of Jas 5:7-20 on community solidarity. This larger pericope is the final section of the Letter and contains an articulate community instruction on what must constitute the religious practices of a distinctively Christian community. The practices include prayer, healing, confession of sins, the forgiveness of sins, and correction. These themes are evidently reflected in 5:13-18 and form the landmarks for the outline or division of the passage into three major units with corresponding subunits. The first part is vv. 13-14 captioned: The Suffering, the Cheerful, and the Sick vis-à-vis the Church, Prayer, and Praise. The second is vv. 15-16 titled: The Prayer of Faith, Confession of Sin, and Healing. Vv. 13-14 serve as an introduction to vv. 15-16; it is especially the prayer expected for the suffering in 13a that is being elaborated by the author in vv. 15-16 regarding the sick. The third is vv. 17-18 on Elijah as a Model of the Righteous at Prayer. Graphically considered the outline of Jas 5:13-18 runs thus:

1) 13-14: The Suffering, the Cheerful, and the Sick vis-à-vis the Church, Prayer, and

Praise

13a The Suffering and Prayer

13b The Cheerful and Praise

14a The Sick and the Church

14b Prayer for the Sick and Anointing with Oil

2) 15-16: The Prayer of Faith, Confession of Sin, and Healing

15a The Prayer of Faith, and the Sick

$15 \mathrm{~b}$ The Lord and Healing

$15 c-16 c$ Confession and Forgiveness of Sin, Prayer and Healing

$15 \mathrm{c}$ Sin and Forgiveness

16a-c Confession of Sins, Prayer, and Healing

$16 \mathrm{~d}$ The Prayer of a Righteous Man

3) 17-18: Elijah as a Model of the Righteous at Prayer 
The outline, therefore, places v. 13 in the first section on suffering, cheerfulness, the Church, prayer, and praise, as well as the sick. The resonance of v. 13 is evident particularly in v. 15 on the theme of prayer and faith. Verse 13 especially is made up of three paratactic units with each constituted by two clauses in rhetorical asyndeton. It is divided into 13a on suffering and prayer and $13 \mathrm{~b}$ on cheerfulness and praise. It is within the context of this outline that the study of v. 13a comes to light. The study of its theme of prayer necessarily extends to 'the prayer of faith' of $v$. $15 \mathrm{a}$ as a subhead.

\subsection{The Suffering One in Jas 5:13a}

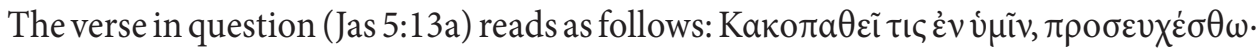
"Is any one among you suffering? Let him pray." Let us start our analysis with the first

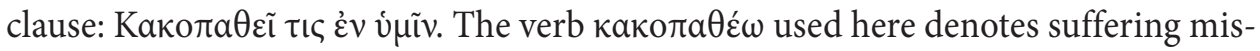
fortune or putting up with hardship patiently. ${ }^{15}$ It implies equally the actual sense of enduring suffering, toil, or exertion or being smitten by misfortune. The physical situations, persecutions, or personal experiences that distress a person (see 2 Tim 2:9; 4:5). It includes military misfortune and personal hardships in life. The noun form

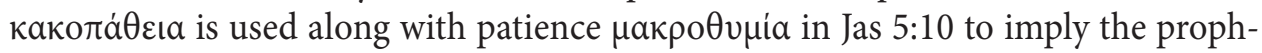
ets' experience and endurance of situations of affliction or suffering. The verb, on the other hand, is used in 5:13 to suggest not principally the distressing situation of misfortune or a specific form of it, but the spiritually distressing sentiment the misfortune brings. ${ }^{16}$ This embraces the inner or mental experience of pains and afflictions, which is in itself, the most tortuous and intangible form of suffering that, can sometimes be incomprehensible to others. The doubts, the anxieties, the absence of good wishes and the inability to avoid or take away displeasing situations from one's experiences render life heavy and unbearable, keeps sleep away and makes the night longer than normal. It is this that most times moves the victim into giving up on life and entering into depression and abandoning even the faith. ${ }^{17}$ This anticipated effect is cautioned against in the 'trials of all kinds' mentioned and provided for in Jas 1:2 and 3-4. In the strict sense of the usage, sickness equally gives rise to this kind of suffering, and the sick are therefore included as enduring this inner suffering. This verse, therefore, prepares the way for v. 14 .

The formulation of the rhetorical question in the singular does not point at any specific person with a specific experience of suffering. It is addressed to all members

\footnotetext{
15 Bauer et al., A Greek Lexicon, 500.

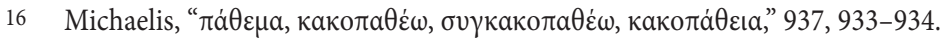

17 Wilkinson, "Healing in the Epistle of James," 327.
} 
of the messianic community $\dot{\varepsilon} v \dot{v} \mu \tilde{\nu} v$ who may find themselves in such situation. This is especially in the context of the continuous struggle between the rich and the poor and the struggle to resist the proposal of the world. Scot McKnight however, suggests that "suffering' in 5:13a most likely refers to the suffering of the poor at the hand of the abusively powerful, and it would also describe the suffering inherent to persevering patience." ${ }^{18}$ Caught in this situation, a Christian may either hold forth or give up, and the author of James thus proposes prayer as a solution by inviting anyone who suffers to pray $\pi \rho \sigma \sigma \varepsilon u \chi \varepsilon \dot{\varepsilon} \sigma \omega$.

\subsection{The Sufferer's Prayer in Jas 5:13a}

The second clause of the verse in question (Jas 15:13a) consists of the imperative

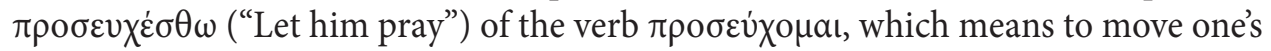
heart, soul, might, and mind or intellect towards God and approach him confidently, to apply oneself in the state of alert and concern to, and occupy oneself entirely with God. This verb means then 'to request,' 'to pray,' 'to call on God,' or 'to approach or come before God.'19

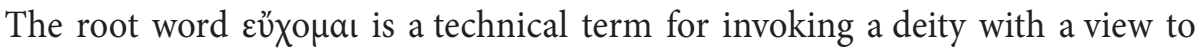
attracting his favourable disposition. It includes any dimension of the invocation, to request, entreat, vow, consecrate etc. The basic meaning of the verb is to make a confident statement about oneself; it also implies 'to boast, brag, or assert'. It means to make supplication to a deity in return for preservation from spiritual, physical, or moral harm. It is founded on a relationship with God in the OT. In this relationship prayer is humanity's means of communication with God, who is identified as the source and mainstay of the universe. It means "to speak to or to make requests of God." ${ }^{20}$ It places humans in converse with God.

In the OT, words like 'to speak,' 'to call upon,' or 'to cry' are often used to denote the act of praying. In the attempt to express an intense emotional involvement the Hebrew would use verbs like 'to groan,' 'to sigh,' or 'to weep.'.21 This captures the exhortation to pray as an invitation to wholeheartedly pour out and make one's entire feeling and sentiments known to God with the confidence that the personal and merciful God hears. Prayer thus "involves the whole person and means that a man comes before God with his whole being and in an attitude of humble submission (Jer 29:12ff)." ${ }^{\prime 2}$ It involves the entire person, flows from the most profound

\footnotetext{
McKnight, The Letter of James, 433.

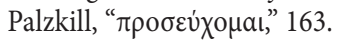

Bauer et al., A Greek Lexicon, 417.

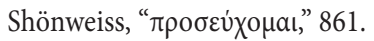

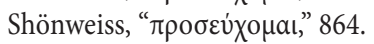


part of one's being (human heart) and reflects one's consciousness of belonging to the community of the people of God. This community itself recognizes and acknowledges God as a person, omniscient, omnipotent, compassionate, and Lord of the whole earth. ${ }^{23}$

To pray therefore is to make a confident statement to God about oneself in a thoroughly personal and specific manner (Gen 28:22-33). It provides for the material and spiritual needs of both the individual and the community. Through it, humankind is sustained in an enduring and intensive Godward orientation while on earth. In that Godward relationship, loneliness is overcome and turned into communion. Prayer expresses the relationship and interface between the believer and God (Jas 5:16). It is "the expression of the believer's experience of proximity to God and dependence on God, thus it also constitutes worship in the real sense." ${ }^{4}$ It consists in an acknowledgement of God's salvific deeds in the past, asking for guidance, liberation from all forms of misfortune, and the courage to face trials.

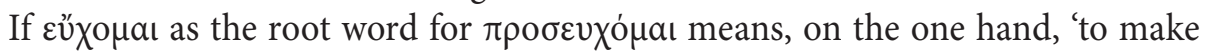
confident statement about oneself, or to boast or assert,' it implies that prayer is an expression of one's trust in God and in his ability to deliver on all that is good. It is a confident statement about the trust one has in God and for which one makes a petition to God. Prayer is a holy boast in the faith and hope of a Christian in God, an assertion of one's confidence in God. That confident statement and the orientation of the entire self and mind towards God together form part of the mechanics that make prayer an encounter that provides, relaxes, and soothes. Prayer is an enrichment that "releases believers from all anxiety concerning their own situation if they but let their requests be made known 'in every respect' ( $\dot{\varepsilon} v \pi \alpha v \tau i$, Phil 4:6) before God...." ${ }^{25}$ It redirects the mind from the multiple anxieties of life towards the one Supreme and

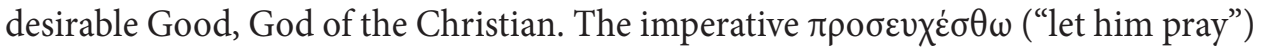
used by James in v. 13a therefore, implies a command deriving from the obligation incumbent on the suffering person as a member of the faith community of God to pray. It is a demand that he or she prays in such a circumstance. What is evident here is the fact that praying is a duty for a member of James' Christian community and at the same time a right that no one can take away from any member. Deprivations that enhance the suffering may exist, but a member of the faith community can never be deprived of the opportunity to pray.

\footnotetext{
23 Naseri, “Reading Luke 15:11-32," 146-147.

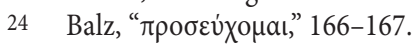

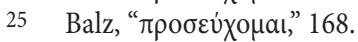




\subsection{The Prayer of Faith in Jas 5:15a}

The nature of this prayer is further elaborated in Jas 5:15a as that which is made from

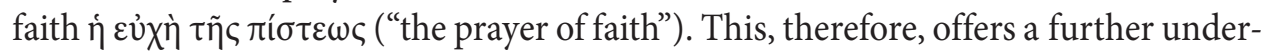
standing of v. 13a; it is then pertinent to give some exegetical explanations to the passage. The noun घủxý may in some contexts mean a solemn oath or vow (see Gen 28:20 LXX) as in the Memorabilia of Xenophon. ${ }^{26}$ This understanding is prevalent in the LXX (Gen 31:13; Num 6:2; Deut 12:6; Ps 49:14; see also Acts 18:18; 21:23). ${ }^{27}$ However, in the Symposium of the same Xenophon, it is also used to imply 'prayer. ${ }^{28}$ Since Jas 5:12 prohibits the use of oath; the author would therefore not be intending oath here; rather eủxý is used here in v. 15 to imply prayer as in the Symposium of Xenophon cited above. It means "a speech or petition directed to God, prayer"29 and shares

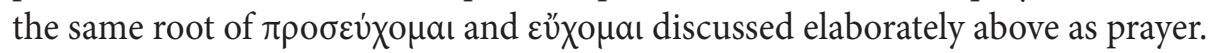

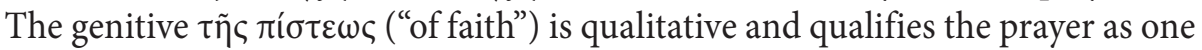
offered out of faith with no doubts (see 1:6), it is not a prayer offered wickedly (4:3). ${ }^{30}$

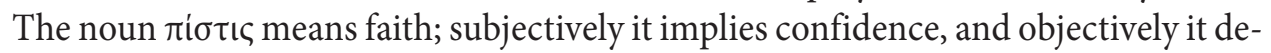

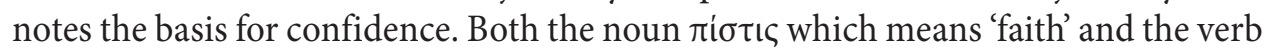
$\pi ı \sigma \tau \varepsilon \dot{v} \omega$ which means 'to believe' or 'to have faith' are used to express the same concept. They are wholesome and regular biblical terms that depict the central theological expression of the relationship of humans to God and God to humans. They constitute consequently, the fundamental nature of the Christian religion. ${ }^{31}$ The lexeme

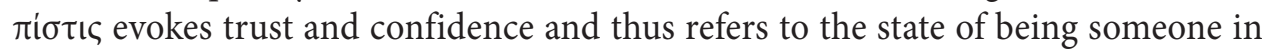
whom confidence is placed. It is anchored on a solemn assurance of faithfulness and loyalty, reliability, and fidelity. In this sense it means 'faithfulness.' It consequently, expresses, on the other hand, the confidence placed on someone or something based on the reliability of the person or thing. It expresses an acknowledgement of the reliability of the person or thing trusted and the consequent movement of the intellect and will towards the person or thing. In this sense, it means 'trust' in the absolute and in the religious sense, and often bears the sense of 'believing.' This is represented especially in the Summa Theologica of Thomas Aquinas as "an act of the intellect assenting to the divine truth at the command of the will moved by the grace of God." ${ }^{32}$

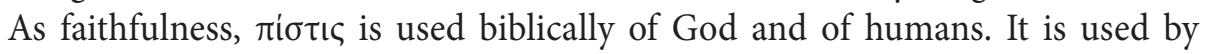
God to express his covenant of faithfulness. On the basis of this divine faithfulness, the chosen people are expected to trustingly act in obedience to the Torah. They

\footnotetext{
Xenophon, Memorabilia 2.2:10.

Bauer et al., A Greek Lexicon, 416.

Xenophon, Symposium 8.15.

Bauer et al., A Greek Lexicon, 416.

Johnson, The Letter of James, 332.

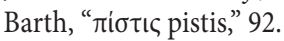

Aquinas, Summa Theologica IIa. IIae, q. 2. a. 9.
} 
act on the confidence that God will be true to his words and bring to fulfilment the promises he made to their progenies. As trust, it is used principally by humans to express their response to this divine faithfulness.

It was equally used in the Greek world to imply 'a token offered as a guarantee of something promised'; in other words, a proof, or a pledge. ${ }^{33}$ This usage is evident in Aristotle. ${ }^{34}$ The keywords, reliability, guarantee, proof, or pledge underscore the sense of provability and certainty. Thus, epistemologically it is possible to speak of the certainty of knowledge in terms of that which a thing is, on the basis of the reliable source of authority that it is so.

The prayer of faith then presupposes a relationship of trust with God, and means an invocation or a petition addressed to God with the conviction that God is faithful and reliable and has the power to generously grant all that is requested of him (Jas 1:5). It is offered by one who, in this relationship of trust with God occupies the self entirely with God. It requires trust in God with no double mind (1:6) as well as faithfulness to God. It is a prayer said 'in the name of the Lord'; an expression of trust in the power, nearness, and faithfulness of the Lord. It is a commitment to God, a prayer said without an iota of doubt (Jas 1:5-8). In this confident expression of prayer, "God's power even the divine authority to hold back and unleash the rains - works at the behest of those groups who claim that God is one, that Jesus is the Messiah, and who back those claims by fulfilling God's whole law through submission to his divine will." ${ }^{35}$ When understood thus, it implies that the invitation directed at the one who suffers to pray in Jas 5:13a is not only about individual prayer, but also the prayer of the Christian community with and for the one suffering. Thus, acknowledging sickness as one of the sources of suffering the author invites the sick in Jas 5:14 to summon the elders of the Church to pray over him and concludes that it is this prayer of faith that will save, heal and bring cheerfulness to the one suffering or sick (v. 15). In the context of the prayer of faith then, the invitation by James to pray in v. 13 is an invitation to express and demonstrate one's faithfulness and commitment to the dependable God in spite of the stress of suffering and the disillusionment it may provoke.

\section{Suffering and Prayer in the Letter of James}

Suffering implies a struggle for freedom from pain and evil and the quest for good. It changes one's outlook on life and predisposes a person to decide on being or not being. As a constituent element in living, it can be tolerated and given meaning

\footnotetext{
33 Bauer et al., A Greek Lexicon, 818.

34 Aristotle, Rhetoric 1.1:3; 3.13.

35 Strange, The Moral World of James, 31.
} 
through a life orientated to suit and respond to the incapacity one experiences. Such discovered sense in suffering through a rediscovered meaning in life provides the suffering person with hope and the maturity and strength to find the reason for living and bearing with pains especially when it is chronic. This rediscovery is offered in the Christian context of James' community by prayer and faith. The author insists especially on eschatological expectation as a solution to the challenges of suffering (1:12). He links suffering to an offence against God and thus the need to pacify God and ask for forgiveness and the restoration of a good relationship with God (5:14-16). Prayer, which is understood as a dialogue between a Christian and God constitutes the basis for this restored relationship.

The mark of the Christian community would not just be their beliefs but also their behaviours in response to misery, economic poverty, and socio-political powerlessness. ${ }^{36}$ As an expression of one's faith in God, prayer in time of suffering, therefore, becomes for James the good work of faith Christians must perform (2:14-24). Just as Abraham accepted the challenge of sacrificing his son to God, James invites Christians to accept their suffering with prayerful resignation to God's will and a renewed commitment to God. This prayerful approach to suffering is to be seen as an accomplishment of the works required of faith in 2:17-24. It is a powerhouse for courage and strength on the part of the one who suffers.

James' invitation to pray asserts the role of prayer in the life of the Christian community as a comprehensive and determined expression of its inner life and state of piety and faith, in a society hostile to believers. It is an expression of self-consciousness and assurance of the helping nearness of God. The call from James implies that those who suffer should not say, "I am being tempted by God" (1:13), or attempt to retaliate against those responsible for the suffering (5:7). They should rather make their cry reach "the ears of the Lord of hosts" (5:4) for the Lord is the one who "gives more grace" to the lowly (4:6). ${ }^{37}$ James is drawing from the Wisdom books of Lamentation, Job, and Psalms on the function of prayer as a coping strategy for those who suffer. ${ }^{38} \mathrm{He}$ depicts prayer as a frank dialogue with God through which those who suffer draw God's attention to their suffering and seek to discover meaning in their suffering. In this prayer, suffering is appreciated as a test of one's faithfulness to God in the form found in Sir 2:4 and Wis 3:5 above.

James' invitation to pray may equally imply hope for the relief of suffering but primarily it is for the steadfast endurance or perseverance to withstand it (5:10). James R. Strange further highlights this position; he notes that James does not present prayer as a request to end suffering rather it is a petition for patience and

36 Wall, "Introduction to Epistolary Literature," 378.

37 Johnson, "The Letter of James," 222.

38 James is scholarly noted to have relied greatly on the OT wisdom literature and is even described as the Wisdom Book of the NT. See Wachob, “The Languages of 'Household' and 'Kingdom,"' 162. 
endurance in the face of suffering. ${ }^{39}$ This understanding underscores the theme of enduring temptation and the reward that comes with it in Jas 1:2-3, 12. Douglas Moo also emphasizes this theme of prayer for endurance, patience, and steadfastness in James:

Perhaps James would include petition to God to remove the trial. But James's concern when he deals with trials elsewhere $(1: 2-4,12 ; 5: 7-11)$ is to encourage believers to endure the suffering with the right spirit and with a divine perspective on history. Presumably, then, the prayer that he encourages here is for the spiritual strength to endure the trial with a godly spirit. ${ }^{40}$

Similarly, R.W. Wall insists on the irreplaceable role James ascribes to prayer in the battle against suffering:

According to James, true religion is congregational and practical more than personal and theologically abstract. The conditions of effective prayer are the community's corporate evaluation of their trials followed by the appropriate congregational response, "Then pray!" Neither retaliate nor acquiesce, which are both self-centered responses, but actively take hardship and heartbreak head-on by praying to the Lord for deliverance. Prayer when rooted in a faith that is as "hard as nails" takes the offensive in redressing the evils of human suffering. ${ }^{41}$

Prayer enhances a Godward relationship in which the 'suffering' who prays dispels loneliness and enters into communion with the other in an ongoing dialogue of encouragement. Through prayer, the 'aloneness' that comes from one's preoccupation with the self gives way to the 'otherness' that derives from preoccupation with the other. This is the self-donation in which suffering when accepted in the light of the vicarious suffering of Christ becomes an occasion for God's will and the benefit of fellow humans. Through prayer, the Christian receives and cultivates an eschatological hope that will in turn assist him or her navigate courageously the challenges of suffering. It is a spiritual dynamism that permits one to reach out beyond the limitation of the body. ${ }^{42}$ In prayer, faith is kept alive and hope is rekindled on the eschatological intervention of the Lord. Because of this hope for the Lord's action, it then becomes difficult for a Christian to give up in the face of challenges.

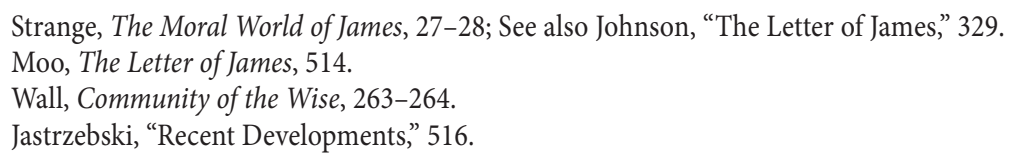




\section{Conclusion}

Suffering in the context of the Christian community of James is identified in Jas 5:13a as referring especially to the inner or mental experience of pains and afflictions. This form of suffering is the most tortuous and intangible, suffering within suffering which, in most times, may be incomprehensible to others. It leads to loss of faith, and consequently loss of hope and loss of the will to live. The invitation to pray in v. 13a has been established above as an invitation to make a confident statement about the trust one has in God and for which one makes a petition to God. The Prayer of faith (v. 15) is similarly understood as an expression of trust in the power, nearness and faithfulness of the Lord. In the context of the Christian religion, 'to pray' is in itself an expression of one's faith in the one to whom the prayer is directed. Consequently, the invitation directed at those who suffer to pray in v. 13a is an invitation to express their faith in God even as they suffer and not renounce God. The invitation identifies the prayer of faith as a petition directed to God without an iota of doubt in God's capacity to generously do everything and provide for the needs of those who trust in him. It is a renewal of the pledge to remain a follower of Christ notwithstanding one's external circumstances. It is a reaffirmation of Ps 116:10 "I trusted even when I said I am sorely afflicted." This prayer, arising from such faith, gives hope to the one who prays. It provides the suffering person with the courage to put up with the displeasing situation, with the hope that it will be better. It works against depression and loss of the will to live.

The author of James knows that suffering can lead to the loss of faith and hope and the will to live. He acknowledges the power, vitality, and connection with God inherent in the prayer of faith. It is this awareness that informs the author's invitation to Christians who suffer to pray in 5:13a. He thus proposes the prayer of faith as the irreplaceable response of a Christian to the challenges posed by suffering. The inner or mental experience of suffering should challenge Christians to pray especially for the courage to put up with the misfortune and not be overcome by it. It denotes the understanding of trials as a test of faith and an opportunity to attain perfection (Jas 1:2-4). The exhortation by James to pray thus implies, in other words, that instead of complaints, passive resignation, or lamentation, 'the suffering persons' should make a confident statement about their conviction and trust in the power of God to provide for and sustain them in their affliction. They should, like the devout Hebrew in the Psalms (30; 50:15; 77; 91:15), cry out to God in faith expecting the just and merciful one to fight their cause, restore their right, and provide them with the grace not to retreat or give in. Conversely, they are to draw from the essential element of prayer, which is submission to God's will (Mark 14:35f; Rom 1:10ff; 2 Cor 12:8f) and receive the grace of endurance and patience. 
Prayer is thus considered, in context, a frank dialogue between the sufferer and God, and in this conversation, it is not the relief from suffering that counts but the possibility to vent the sufferer's frustration and be relieved. It provides a coping strategy for those who suffer as they express their confidence in God. Members of James' messianic community are expected in their suffering to appropriate the words of the Psalms of Solomon 15:1: "When I was persecuted I called on the Lord's name; I expected the help of Jacob's God and I was saved. For you, O God, are the hope and refuge of the poor." The intervention of God in the situation of conflict is always the right of his people who suffer. It is therefore their right to implore God through prayers for support and companionship. Prayer, therefore, becomes a continuous communion with God as the source of the community, an expression of trust in the God who is known to answer the call of his people (Ps 65:3). It serves as a reminder to God of his promises and salvific acts. The Christian community of James is expected especially to base its prayers on the unqualified faith in the salvation brought forth by God in Christ.

\section{Bibliography}

Albl, M.C., "'Are Any among You Sick?' The Health Care System in the Letter of James," Journal of Biblical Literature 121/1 (2002) 123-143.

Aquinas, Thomas, Summa Theologica Part II-II (Secunda Secundae) (trans. Fathers of the English Dominican Province) (New York: Benziger Brothers 2006) [e-Book].

Aristole, Art of Rhetoric (trans. J.H. Freese - G. Striker) (Loeb Classical Library 193; Cambridge: Harvard University Press 2020).

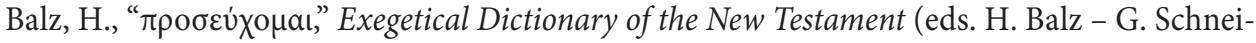
der) (Grand Rapids, MI: Eerdmans 1993) III, 164-169.

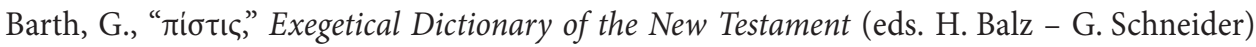
(Grand Rapids, MI: Eerdmans 1993) III, 91-97.

Bauer, W. et al., A Greek Lexicon of the New Testament and other Early Christian Literature, 3 ed. (ed. F.W. Danker) (Chicago, IL: Chicago University Press 2000).

Bowden, A., "An Overview of the Interpretive Approaches to James 5.13-18," Currents in Biblical Research 13/1 (2014) 67-81.

Bukovsky, J., "Suffering," New Catholic Encyclopedia (Washington, D.C.: Catholic University of America 1967) XIII, 775-776.

Condon, K., "The Sacrament of Healing (James 5:14-15)," Scripture 11 (1959) 33-42.

Davids, P.H., The Epistle of James (Grand Rapids, MI: Eerdmans 1982).

Jastrzebski, A.K., "Recent Developments in Understanding Spirituality as Exemplified by the Concept of Self-Transcendence," Verbum Vitae 39/2 (2021) 515-525.

Johnson, L.T., “The Letter of James," The New Interpreter's Bible (ed. L.E. Keck) (Nashville, TN: Abingdon 1998) XII, 175-243.

Johnson, L.T., The Letter of James (New York: Doubleday 1995). 


\section{CHRISTOPHER NASERI}

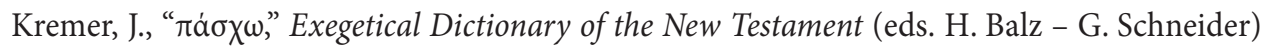
(Grand Rapids, MI: Eerdmans 1993) III, 51-52.

Laws, S., "James, Epistle of," Anchor Bible Dictionary (eds. D.N. Freedman) (New York: Doubleday 1992) III, 621-628.

McKnight, S., The Letter of James (Grand Rapids, MI: Eerdmans 2011).

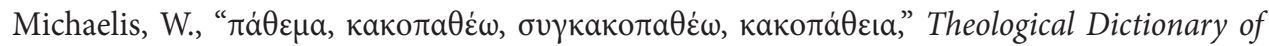
the New Testament (eds. G. Kittel - G. Friedrich) (Grand Rapids, MI: Eerdmans 1967) V, 930-935, 936-938.

Moo, D.J., The Letter of James (Grand Rapids, MI: Eerdmans 2000).

Naseri, C., "Reading Luke 15:11-32 as the Parable of Mercy and Compassion," Mercy and Justice in the Bible (eds. B.O. Ukwuegbu et al.) (Port Harcourt: Catholic Biblical Association of Nigeria 2017) 142-159.

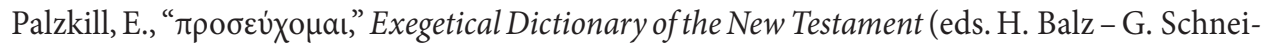
der) (Grand Rapids, MI: Eerdmans 1993) III, 163-164.

Rehnsfeldt, A. - Eriksson, K., “The Progression of Suffering Implies Alleviated Suffering," Scandinavian Journal of Caring Science 18 (2004) 264-272.

Rudolfsson, G. - Flensner, G., "Suffering and Suffering with the Other: Perspective of Perioperative Nurse Leaders," Journal of Nursing Management 20 (2012) 278-286.

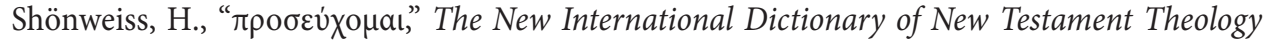
(ed. C. Brown) (Grand Rapids, MI: Zondervan 1976) II, 861-864.

Simundson, D.J, "Suffering," The Anchor Bible Dictionary (ed. D.N. Freedman) (New York: Doubleday 1992) VI, 219-225.

Strange, J.R., The Moral World of James. Setting the Epistle in Its Greco-Roman and Judaic Environment (New York: Lang 2010).

Ten Have, H.A.M.J., "Health Care and the Human Body," Medicine, Health Care and Philosophy 1 (1998) 103-105.

Tripp, P.D., Suffering. Gospel Hope When Life Doesn't Make Sense (Wheaton, IL: Crossway 2018). Wachob, W.H., "The Languages of 'Household' and 'Kingdom' in the Letter of James: A Socio-Rhetorical Study," Reading James with New Eyes. Methodological Reassessments of the Letter of James (eds. R.L. Webb - J.S. Kloppenborg) (London: Clark 2007) 151-168.

Wall, R.W., Community of the Wise. The Letter of James (Valley Forge, PA: Trinity Press 1997).

Wall, R.W., "Introduction to Epistolary Literature," The New Interpreter's Bible (ed. L. Keck) (Nashville, TN: Abingdon 2002) X, 369-391.

Wilkinson, J., "Healing in the Epistle of James," Scottish Journal of Theology 24 (1971) 326-345.

Xenophon, Memorabilia, Oeconomicus, Symposium, Apologia (trans. E.C. Marchant - O.J. Todd)

(Loeb Classical Library 168; Cambidge: Harvard University Press 1923). 